\title{
ATRYBUTY I CZYNNIKI SUKCESU PARTNERSTWA PRZEDSIĘBIORSTW
}

\begin{abstract}
Budowanie przez przedsiębiorstwa partnerskich relacji staje się coraz bardziej popularnym sposobem na utrzymywanie przewagi konkurencyjnej. Umiejętność budowania, rozwoju i ciągłego doskonalenia partnerskich relacji na rynku przedsiębiorstw jest obecnie jednym z kluczowych warunków ich skutecznego wzrostu zewnętrznego. Obecnie relacje te są budowane i rozwijane w wielu gałęziach przemysłu. Zarówno w literaturze, jak i w praktyce gospodarczej pojęcie partnerstwa jest różnorodnie interpretowane, co skutkuje jego płynnością terminologiczną.

Celem artykułu jest wskazanie kluczowych atrybutów i czynników sukcesu partnerskich relacji między przedsiębiorstwami. Postawiony cel determinuje wybór takich metod badawczych, jak: analiza piśmiennictwa krajowego i zagranicznego oraz wnioskowanie dedukcyjne.

W świetle przedstawionych ujęć definicyjnych i atrybutów partnerstwa przyjęto, że partnerstwo przedsiębiorstw to dobrowolne i dynamiczne relacje tworzone dla osiagnnięcia wspólnych celów, prowadzące do uzyskania dodatkowych efektów synergicznych i przewagi konkurencyjnej. Specyficznymi cechami tego typu relacji, nazwanymi również atrybutami czy osobliwościami, są przede wszystkim: wzajemne zaufanie partnerów, ich zaangażowanie we wspólne działania, wymiana informacji (otwarta i intensywna komunikacja) oraz podział ryzyka i korzyści. Można wyróżnić następujące kluczowe czynniki stymulujące rozwój relacji o charakterze partnerskim: przebieg dotychczasowej współpracy z danym partnerem, pozytywne doświadczenia wynikające ze współpracy z innymi podmiotami, wzajemny szacunek i zaufanie, dążenie partnerów do realizacji jasno określonych celów o charakterze strategicznym, wzajemne dzielenie się informacjami, wspólne rozwiązywanie problemów, zaangażowanie partnerów w budowanie i ciągłe doskonalenie relacji.
\end{abstract}

Słowa kluczowe: partnerstwo, relacje, atrybuty, czynniki sukcesu

\section{WPROWADZENIE}

W obecnych realiach gospodarczych relacje międzyorganizacyjne charakteryzuje wysoka złożoność i zmienność, co niewątpliwie wiąże się z oddziaływaniem różnorodnych czynników o endo- i egzogenicznym charakterze. Nieprzewidywalne i labilne otoczenie, złożone kluczowe warunki rozwojowe współczesnych przedsiębiorstw oraz tempo zmian w gospodarce $^{2}$ wymuszają na nich obranie właściwego kierunku rozwoju. Przedsiębiorstwa mogą z jednej strony ,próbować działać samodzielnie, z drugiej zaś mogą pójść w kierunku różnego rodzaju form współpracy międzyorganizacyjnej”3. Na podstawie obserwacji praktyki

\footnotetext{
${ }^{1}$ Mgr Magdalena Szydełko, Katedra Systemów Zarządzania i Logistyki, Wydział Zarządzania, Politechnika Rzeszowska, Al. Powstańców Warszawy 8, 35-959 Rzeszów, tel.: (17) 86514 93, e-mail: mszydel@prz.edu.pl.

${ }^{2}$ M. Szydełko, Ł. Szydełko, Benchmarking w podejściu procesowym $w$ przedsiębiorstwie - wybrane zagadnienia, „Modern Management Review” XVIII/2 (2013), s. 103.

${ }^{3}$ J. Niemczyk, B. Jasiński, Wstęp, [w:] Sieci międzyorganizacyjne. Wspótczesne wyzwanie dla teorii i praktyki zarzqdzania, red. J. Niemczyk, E. Stańczyk-Hugiet, B. Jasiński, C.H. Beck, Warszawa 2012, s. 10.
} 
gospodarczej, jak również analizy teoretycznych rozważań i wyników badań relacji międzyorganizacyjnych zawartych w literaturze przedmiotu ${ }^{4}$ nasuwają się wnioski, że obecnie tradycyjna walka z konkurentami należy już do przeszłości, a przedsiębiorstwa ewoluują wraz ze zmieniającym się otoczeniem, redefiniują relacje i wchodzą w nowe formy związków z pozostałymi podmiotami gospodarczymi. Jak podkreśla Ewa Stańczyk-Hugiet: „,wielu autorów uznaje paradygmat relacji, ale wciąż pozostaje on $w$ fazie formowania, a relacje międzyorganizacyjne w ostatnich latach są przedmiotem badań $\mathrm{z}$ tego względu, że coraz więcej organizacji poprzez kształtowanie właśnie relacji kształtuje swoją strategiczną ścieżkę rozwoju"5. Ponadto więzi z podmiotami funkcjonującymi w ramach ich łańcuchów wartości, a także z partnerami dysponującymi komplementarnymi zasobami sprzyjają wzmacnianiu zdolności przedsiębiorstwa do skutecznego rywalizowania na rynku ${ }^{6}$. Proces kształtowania relacji międzyorganizacyjnych, w tym partnerskich relacji współdziałania przedsiębiorstw, stanowi współcześnie jedno z kluczowych wyzwań zarządzania strategicznego. Związane jest to z trzema megatrendami we współczesnej gospodarce:

- dekonstrukcją łańcucha wartości, która implikuje potrzebę współdziałania przedsiębiorstw ze względu na specjalizację i ekonomię skali;

- hiperkonkurencją prowadzącą do ,erozji” przewagi konkurencyjnej, która wymusza na przedsiębiorstwach zachowania elastyczne;

- sieciowością polegającą na tworzeniu się grup współdziałających podmiotów ${ }^{7}$.

W szerszy kontekst postulowanych obecnie w naukach o zarządzaniu paradygmatów relacji i współdziałania przedsiębiorstw wpisuje się koncepcja partnerstwa przedsiębiorstw. W tym miejscu należy podkreślić, że partnerstwo jako „wyższy poziom relacji biznesowych"8 $\mathrm{i}$ modus operandi przedsiębiorstw w trzecim tysiącleciu sugerują „,nową jakość w kontaktach i komunikacji między uczestnikami biznesu"9. Ponadto umiejętność nawiązywania i rozwoju partnerskich relacji międzyorganizacyjnych staje się dzisiaj ,podstawową kompetencją dla coraz większej liczby organizacji”,10.

W związku z tym myślą przewodnią prowadzonych rozważań jest stwierdzenie, że umiejętność budowania, rozwoju i ciąłego doskonalenia partnerskich relacji na rynku przedsiębiorstw staje się dzisiaj jednym z kluczowych warunków skutecznego wzrostu zewnętrznego $^{11}$. Przedsiębiorstwa, przyjmując za podstawę rozwoju nawiązywanie

${ }^{4}$ Zob. J. Moore, S.R. Curry, The Death of Competition, „Fortune” 133/7 (1996), s. 142-144; G. Hamel, Y.L. Doz, C.K. Prahalad, Collaborate with Your Competitors and Win, „Harvard Business Review” 67/1 (1989), s. 133-139; W. Czakon, A.S. Fernandez, A. Minà, Editorial - From Paradox to Practice: the Rise of Coopetition Strategies, „International Journal of Business Environment” 6/1 (2014), s. 1-10; W. Czakon, M. Rogalski, Coopetition Typology Revisited - a Behavioural Approach, „International Journal of Business Environment" 6/1 (2014), s. 28-46.

${ }^{5}$ E. Stańczyk-Hugiet, Dynamika strategiczna w ujęciu ewolucyjnym, Wydawnictwo Uniwersytetu Ekonomicznego we Wrocławiu, Wrocław 2013, s. 52.

${ }^{6}$ A. Sudolska, Partnerstwo przedsiębiorstw jako czynnik rozwoju ich kompetencji strategicznych, „Prace Naukowe Uniwersytetu Ekonomicznego we Wrocławiu” 2010/116, s. 418.

${ }^{7}$ W. Czakon, Koordynacja sieci - wieloraka forma organizacji, „Przegląd Organizacji” 2008/9, s. 7-10.

${ }^{8}$ E. Rigsbee, PartnerSHIFT. How to Profit from the Partnering Trend, John Wiley and Sons, New York 2000 , s. 2.

${ }^{9}$ D. Kempny, Logistyczna obstuga klienta, PWE, Warszawa 2001, s. 280.

${ }^{10}$ D. Latusek-Jurczak, Formy wspótpracy międzyorganizacyjnej, [w:] Relacje międzyorganizacyjne w naukach o zarzq̨dzaniu, red. A. K. Koźmiński, D. Latusek-Jurczak, Wolters Kluwer business, Warszawa 2014, s. 46.

${ }^{11}$ Wzrost zewnętrzny, w odróżnieniu od wewnętrznego, w którego wypadku podmiot rozwija się, bazując na własnym potencjale, to oparcie rozwoju przedsiębiorstwa na współdziałaniu. Zob. H. Jagoda, B. Haus, Holding - organizacja i funkcjonowanie, PWE, Warszawa 1995, s. 45. 
partnerskich relacji $\mathrm{z}$ pozostałymi podmiotami gospodarczymi, zarówno w ramach współpracy, jak i koopetycji, niewątpliwie zwiększają szansę na osiągnięcie wielu strategicznych korzyści oraz uzyskanie i skuteczne utrzymywanie przewagi konkurencyjnej.

Partnerstwo przedsiębiorstw, ,jak to bywa w każdej wstępnej fazie rozwoju kolejnego paradygmatu" ${ }^{\prime 2}$, jest pojęciem nie do końca precyzyjnie zdefiniowanym w literaturze przedmiotu. Ponadto zagadnienia atrybutów i czynników sukcesu partnerskich relacji na rynku przedsiębiorstw pozostają nadal słabo rozpoznane. Wskazana luka poznawcza w obszarze relacji międzyorganizacyjnych wymaga istotnego wysiłku teoriotwórczego, a także dogłębnych badań. Niniejszy artykuł stanowi przyczynek do wypełnienia tej luki. Intencją autorki jest przedstawienie złożoności tego zagadnienia oraz najistotniejszych wniosków, które będą miały wpływ na dalsze badania prowadzone w przyszłości. Celem artykułu jest wskazanie kluczowych atrybutów i czynników sukcesu partnerskich relacji między przedsiębiorstwami. Postawiony cel determinuje wybór takich metod badawczych, jak: analiza piśmiennictwa krajowego i zagranicznego oraz wnioskowanie dedukcyjne.

\section{RÓŻNORODNOŚĆ DEFINICYJNA PARTNERSTWA PRZEDSIĘBIORSTW}

Pojęcie partnerstwa ewokuje bogaty wachlarz skojarzeń, które powstają na skutek posługiwania się tym terminem w sensie potocznym i naukowym. Zarówno w literaturze z zakresu nauk o zarządzaniu, jak i w praktyce gospodarczej pojęcie partnerstwa jest różnorodnie interpretowane, a czasami nawet używane w niewłaściwych kontekstach. Słowo „partnerstwo” w aktualnych realiach gospodarczych jest niezwykle popularne i coraz trudniej o pewność, czy w ogóle jeszcze cokolwiek znaczy. Używa się go bowiem na wiele różnych sposobów, a całkiem nierzadko na mocy swojej popularności, po prostu jako ,słowo-wytrych towarzyszące wszelkim przejawom współdziałania gospodarczego",13.

Punktem wyjścia do dalszej analizy jest przegląd wybranych definicji partnerstwa, jako kategorii relacji międzyorganizacyjnych na rynku przedsiębiorstw. Zaczerpnięte z literatury przedmiotu definicje i sformułowania odnoszące się do partnerstwa przedstawiono w tabeli 1. Analiza ujęć definicyjnych partnerstwa potwierdza jego wieloznaczność i wieloaspektowość. Partnerstwo przedsiębiorstw jest postrzegane przez badaczy jako:

- relacja międzyorganizacyjna;

- forma realizacji międzyorganizacyjnych strategii;

- specyficzny rodzaj strategii realizacji współpracy międzyorganizacyjnej;

- metoda zarządzania;

- proces współdziałania;

- długoterminowa strategia biznesowa;

- względnie trwały związek;

- czyste stosunki współpracy;

- rodzaj kooperacji;

- alians lub koalicja;

\footnotetext{
${ }^{12}$ J. Niemczyk, B. Jasiński, op. cit., s. 9.

${ }^{13}$ A. Adamik, Rola kadry kierowniczej w budowie partnerstwa przedsiębiorstw, [w:] Organizacja i kierowanie, nr 3 (156), Komitet Nauk Organizacji i Zarządzania PAN i Kolegium Zarządzania i Finansów Szkoły Głównej Handlowej, Warszawa 2013, s. 122.
} 
- jeden z mechanizmów koordynacji rynkowej.

Tabela 1. Definiowanie partnerstwa według wybranych autorów

\begin{tabular}{|c|c|}
\hline Autor, rok & Interpretacja pojęcia „partnerstwo” \\
\hline $\begin{array}{l}\text { J. Mohr, } \\
\text { R. Spekman } \\
(1994)\end{array}$ & $\begin{array}{l}\text { Partnerstwo to celowe, strategiczne relacje między niezależnymi firmami, } \\
\text { które realizują kompatybilne cele, dążą do osiagnięcia obustronnych korzy- } \\
\text { ści i akceptują wysoki poziom wzajemnej zależności }{ }^{14} \text {. }\end{array}$ \\
\hline $\begin{array}{l}\text { L.G. Crowley, } \\
\text { M.A. Karim } \\
\text { (1995) }\end{array}$ & $\begin{array}{l}\text { Partnerstwo może być postrzegane jako organizacja, która powstała w wy- } \\
\text { niku implementacji strategii kooperacyjnej, w celu modyfikacji granic mię- } \\
\text { dzy autonomicznymi przedsiębiorstwami na konkurencyjnym rynku }{ }^{15} \text {. }\end{array}$ \\
\hline $\begin{array}{l}\text { M.D. Hutt, } \\
\text { T.W. Speh } \\
\text { (1997) }\end{array}$ & $\begin{array}{l}\text { Partnerstwo przedsiębiorstw odnosi się do czystych stosunków współpracy, } \\
\text { w których wypadku wraz z upływem czasu strony układu tworzą silne i } \\
\text { rozległe więzi społeczne, ekonomiczne, usługowe i techniczne, w celu uzy- } \\
\text { skania obopólnych korzyści }{ }^{16} \text {. }\end{array}$ \\
\hline $\begin{array}{l}\text { A. Sulejewicz } \\
\text { (1997) }\end{array}$ & $\begin{array}{l}\text { Partnerstwo strategiczne jest formą realizacji międzyorganizacyjnych strate- } \\
\text { gii co najmniej dwóch partnerów, którzy zachowują wspólnie uzgodnioną } \\
\text { autonomię i pozostają niezależnymi podmiotami w obszarze działań nie- } \\
\text { wchodzących w zakres porozumienia. Zachodzi równość: partnerstwo stra- } \\
\text { tegiczne }=\text { alians strategiczny = strategia partnerska = koalicja }{ }^{17} \text {. }\end{array}$ \\
\hline $\begin{array}{l}\text { E. Rigsbee } \\
(2000)\end{array}$ & $\begin{array}{l}\text { Partnerstwo to proces współdziałania realizowany przez przynajmniej } \\
\text { dwóch uczestników relacji, w celu osiagania korzyści synergicznych. Jeżeli } \\
\text { partnerstwo jest długoterminową strategią biznesową, zapewnia synergiczne } \\
\text { rozwiązania dla współczesnych wyzwań biznesowych }{ }^{18} \text {. }\end{array}$ \\
\hline $\begin{array}{l}\text { D. Kempny } \\
\text { (2001) }\end{array}$ & $\begin{array}{l}\text { Partnerstwo to długookresowy, względnie trwały związek, przynajmniej } \\
\text { między dwoma partnerami, oparty na wzajemnym zaufaniu i otwartej wy- } \\
\text { mianie informacji oraz wspólnym dzieleniu się ryzykiem i korzyściami } \\
\text { współpracy }{ }^{19} \text {. }\end{array}$ \\
\hline $\begin{array}{l}\text { L.W. Stern, } \\
\text { A.I. El-Ansary, } \\
\text { A.T. Coughlan } \\
(2002)\end{array}$ & 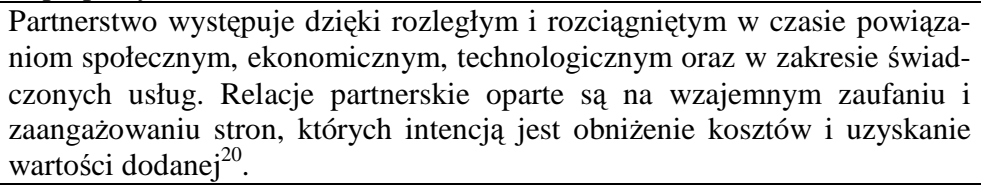 \\
\hline
\end{tabular}

${ }^{14}$ J. Mohr, R. Spekman, Characteristics of Partnership Success: Partnership Attributes, Communication Behavior, and Conflict Resolution Techniques, ,Strategic Management Journal” 15/2 (1994), s. 135.

${ }^{15}$ L.G. Crowley, M.A. Karim, Conceptual Model of Partnering, ,Journal of Management in Engineering” 11/5 (1995), s. 33-39.

${ }^{16}$ M.D. Hutt, T.W. Speh, Zarzqdzanie marketingiem. Strategia rynku dóbr i ustug przemysłowych, PWN, Warszawa 1997, s. 116.

17 A. Sulejewicz, Partnerstwo strategiczne: modelowanie wspótpracy przedsiębiorstw, Oficyna Wydawnicza Szkoły Głównej Handlowej, Warszawa 1997, s. 72.

${ }^{18}$ E. Rigsbee, op. cit., s. 1-2.

${ }^{19}$ D. Kempny, op. cit..

${ }^{20}$ L.W. Stern, A.I. El-Ansary, A.T. Coughlan, Kanaty marketingowe, PWN, Warszawa 2002, s. 44. 


\begin{tabular}{|c|c|}
\hline Autor, rok & Interpretacja pojęcia „partnerstwo” \\
\hline $\begin{array}{l}\text { J.M. Brinkerhoff } \\
(2002)\end{array}$ & $\begin{array}{l}\text { Partnerstwo jest dynamiczną relacją między różnymi podmiotami, bazująca } \\
\text { na wspólnie uzgodnionych celach i porozumieniu co do najbardziej racjo- } \\
\text { nalnego podziału pracy, przy uwzględnieniu porównywalnych korzyści dla } \\
\text { każdego partnera. Partnerstwo obejmuje wzajemne oddziaływania, z zacho- } \\
\text { waniem równowagi między synergią i odpowiednią autonomia, z którą } \\
\text { wiążą się wzajemny szacunek, równy udział w podejmowaniu decyzji, } \\
\text { wzajemna odpowiedzialność i transparentnośćc }{ }^{21} \text {. }\end{array}$ \\
\hline $\begin{array}{l}\text { J. Witkowski } \\
(2003)\end{array}$ & $\begin{array}{l}\text { Partnerstwo to kształtowanie stosunków gospodarczych między poszczegól- } \\
\text { nymi uczestnikami (ogniwami) na zasadach zaufania, podziału ryzyka i } \\
\text { korzyści, prowadzące do uzyskania dodatkowych efektów synergicznych i } \\
\text { przewagi konkurencyjnej }{ }^{22} \text {. }\end{array}$ \\
\hline $\begin{array}{l}\text { A. Mezzadri } \\
(2008)\end{array}$ & $\begin{array}{l}\text { Partnerstwo to współpraca pomiędzy organizacjami, w której ramach udział } \\
\text { i wzajemne oddziaływanie uczestników mogą mieć różne natężenie }{ }^{23} \text {. }\end{array}$ \\
\hline $\begin{array}{l}\text { S. Peace } \\
(2010)\end{array}$ & $\begin{array}{l}\text { Partnerstwo to metoda zarządzania stosowana przez co najmniej dwie orga- } \\
\text { nizacje, która prowadzi do uzyskania określonych celów biznesowych przez } \\
\text { maksymalizację wydajności wykorzystania zasobów stron relacji }{ }^{24} \text {. }\end{array}$ \\
\hline $\begin{array}{l}\text { A. Sudolska } \\
(2011)\end{array}$ & $\begin{array}{l}\text { Partnerstwo to pojęcie wykorzystywane do oddania istoty ścisłej współpracy } \\
\text { przedsiębiorstw. W partnerskim układzie kooperacji przedsiębiorstw ich } \\
\text { wspólnym celem strategicznym jest wzrost wartości, będącej udziałem } \\
\text { zaangażowanych w daną relację partnerów }{ }^{25} \text {. }\end{array}$ \\
\hline $\begin{array}{l}\text { A. Adamik } \\
(2013)\end{array}$ & $\begin{array}{l}\text { Partnerstwo jest rodzajem kooperacji, jednym z mechanizmów koordynacji } \\
\text { rynkowej (oprócz konkurencji i kontroli) i specyficznym rodzajem strategii } \\
\text { realizacji współpracy międzyorganizacyjnej co najmniej dwóch partnerów, } \\
\text { zachowujących wspólnie uzgodnioną autonomię i pozostających niezależ- } \\
\text { nymi jednostkami w zakresie działań niewchodzących w obszar układu } \\
\text { partnerskiego }{ }^{26} \text {. }\end{array}$ \\
\hline
\end{tabular}

Źródło: opracowanie na podstawie opisów źródłowych.

Należy podkreślić, że pomiędzy przytoczonymi w tabeli 1 definicjami partnerstwa nie zachodzą wyraźne sprzeczności czy nieciaggłości w rozwoju rozumienia tego pojęcia. Były one formułowane na różne potrzeby badawcze i na zróżnicowanym gruncie teoretycznym. Na uwagę zasługuje również fakt, że w wielu definicjach partnerstwa przedsiębiorstw zaprezentowanych $\mathrm{w}$ literaturze przedmiotu pojawiają się takie pojęcia jak: współpraca, współdziałanie i kooperacja. Są one traktowane wręcz jako podstawa budowy partnerstwa przedsiębiorstw i za ich pomocą badacze najczęściej definiują partnerstwo na rynku przedsiębiorstw. Analiza różnych interpretacji teoretycznych zawartych w literaturze

${ }^{21}$ J.M. Brinkerhoff, Government - Nonprofit Partnership: a Defining Framework, „Public Administration and Development" 22/1 (2002), s. 21.

${ }^{22}$ J. Witkowski, Zarzqdzanie tańcuchem dostaw. Koncepcje, procedury, doświadczenia, PWE, Warszawa 2003, s. 34.

${ }^{23}$ A. Mezzadri, Le partnership tra imprese e organizzazioni non profit, Universitŕ del Sacro Cuore, Milano 2008 , s. 9.

${ }^{24}$ S. Peace, Partnerstwo w budownictwie, Poltext, Warszawa 2010, s. 19.

${ }^{25}$ A. Sudolska, Uwarunkowania budowania relacji proinnowacyjnych przez, przedsiębiorstwa $w$ Polsce, Wydawnictwo Naukowe Uniwersytetu Mikołaja Kopernika, Torun 2011, s. 25-26.

${ }^{26}$ A. Adamik, A partnering approach to extending the business base through cooperation with competitors (coopetition) - is it an option for SMEs?, [w:] Recent Advances in Management, Marketing and Finances, red. A. Zaharim, R.G. Rodrigues, „Business and Economics Series” No. 4, WSEAS Press, Cambridge 2013, s. 59. 
przedmiotu prowadzi do konstatacji, że pojęcia kooperacji, współpracy i współdziałania są często traktowane synonimicznie i zamiennie stosowane w kontekście relacji o charakterze melioratywnym na rynku przedsiębiorstw. Ze względu na bliskość znaczeniową, zabieg zamiennego stosowania pojęć współpracy i współdziałania jest uzasadniony. Natomiast zamienne używanie pojęć kooperacji i współpracy gospodarczej w każdej sytuacji jest niewłaściwym zabiegiem ${ }^{27}$. Uściślając - każdy związek kooperacyjny z zachowaniem samodzielności prawnej i ekonomicznej podmiotów jest formą współpracy, natomiast nie każda współpraca (na przykład związki koncentracyjne, takie jak fuzje czy przejęcia) może być określana mianem kooperacji.

Należy również wskazać na zjawisko nadużywania słowa ,partner”, zarówno w praktyce gospodarczej, jak i w teorii zarządzania. Oznacza to, że uczestnicy (strony) różnego rodzaju relacji międzyorganizacyjnych nazywani są partnerami ${ }^{28}$. Jest to niewątpliwie jedna z przyczyn rozmycia definicyjnego pojęcia partnerstwa. Pojawia się zatem pytanie, czy zabieg językowy polegający na zamiennym używaniu pojęć: partner i uczestnik relacji jest właściwy. Z całą stanowczością należy stwierdzić, że każdy partner jest uczestnikiem relacji, ale nie każda relacja nosi znamiona partnerskiej, a tym samym nie każdy uczestnik relacji może być określany mianem partnera.

Syntetyczne ujęcie istoty partnerstwa na podstawie literatury przedmiotu nie jest łatwym zadaniem, ponieważ autorzy tworzą różne konstrukty do opisu tego samego zjawiska. Mając świadomość wystąpienia trudności w wyjaśnieniu pojęcia partnerstwa, podjęto próbę określenia i uporządkowania znaczeń związanych z partnerstwem na rynku przedsiębiorstw (business-to-business). Wiąże się to niewątpliwie ze wskazaniem jego specyficznych cech (atrybutów, osobliwości).

\section{ATRYBUTY PARTNERSKICH RELACJI NA RYNKU PRZEDSIĘBIORSTW}

Partnerskie relacje międzyorganizacyjne stanowią bardzo złożone układy współpracy. Mogą zaistnieć między podmiotami będącymi rywalami rynkowymi, jak również mogą być budowane przez przedsiębiorstwa niekonkurujące ze sobą. Ponadto partnerstwo może być kształtowane w praktyce w ramach różnych form organizacyjnych, na przykład stowarzyszeń branżowych czy klastrów.

Pluralizm epistemologiczny doprowadził do sformułowania przez badaczy wielu cech partnerskich relacji między przedsiębiorstwami, które dotyczą układów bilateralnych i wielostronnych. W tabeli 2 przedstawiono zestaw atrybutów partnerstwa wskazywanych w literaturze przedmiotu. Są wyznaczane przez skrzyżowanie wierszy (wymiarów partnerstwa) i kolumn (właściwości wymiarów) w zacienionych polach z symbolem „,”. Przykładami atrybutów odczytanych w podany sposób są:

- relacje: wzajemne, długoterminowe, dobrowolne, silne, rozległe, trwałe, dynamiczne;

- zaufanie: wzajemne;

- korzyści: wspólnie uzgodnione, synergiczne, wspólnie dzielone;

\footnotetext{
${ }^{27}$ Nowak, B. Stępień, Powiqzania kooperacyjne - wstęna charakterystyka relacji, [w:] Międzynarodowa kooperacja gospodarcza z polskiej perspektywy, red. B. Stępień, PWE, Warszawa 2011, s. 25.

${ }^{28}$ Zob. S. Kock, M. Bengtsson, S. Slotte-Kock, To Compete or Cooperate - A Strategic Dilemma, „Journal of Business \& Industrial Marketing" 18/1 (2003), s. 6-21; N.J. Foss, B.B. Nielsen, Researching Multilevel Phenomena: The Case of Collaborative Advantage in Strategic Management, ,Journal of Centrum Cathedra” 5/1 (2012), s. 11-23.
} 
- współpraca: długoterminowa, intensywna, otwarta;

- autonomia: wspólnie uzgodniona;

- uczenie się: wzajemne;

- szacunek: wzajemny.

Tabela 2. Atrybuty partnerstwa przedsiębiorstw

\begin{tabular}{|l|l|l|l|l|l|l|l|l|l|}
\hline & & & & & & \\
\hline
\end{tabular}

Źródło: opracowanie własne.

Analizując istotę partnerskich relacji między przedsiębiorstwami, należy stwierdzić, że źródła literaturowe wskazują najczęściej sześć cech pozwalających wyjaśnić ich oryginalność. Są to: wzajemne zaufanie, wzajemne zaangażowanie, otwarta wymiana informacji, wspólnie uzgodniona autonomia oraz podział ryzyka i korzyści.

\section{CZYNNIKI SUKCESU PARTNERSTWA PRZEDSIĘBIORSTW}

Koncentrując rozważania na partnerstwie przedsiębiorstw, należy stwierdzić, że wieloaspektowa dyskusja wymaga również wskazania czynników wpływających na jego sukces. Należy zauważyć, że zdefiniowanie pojęcia sukcesu partnerstwa, a także wskazanie 
jego miar sprawiają badaczom trudność. Mogą być analizowane na przykład w kategoriach wyników finansowych lub celów biznesowych ${ }^{29}$.

Przegląd literatury eksplorującej zagadnienie czynników sukcesu partnerstwa upoważnia również do stwierdzenia, że problematyka ta jest złożona, wielowymiarowa, a przede wszystkim stosunkowo słabo rozpoznana na gruncie polskich badań. Graficzne ujęcie czynników sukcesu z podziałem na atrybuty, proces komunikacji i techniki rozwiązywania konfliktów przedstawiono na rysunku 1.

Rysunek. 1. Czynniki sukcesu partnerstwa przedsiębiorstw

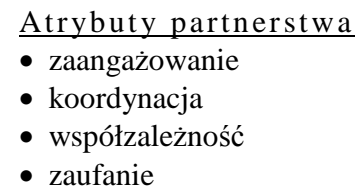

- zaangażowanie

- koordynacja

- współzależność

- zaufanie

\section{Proces komunikacji \\ - jakość \\ - dzielenie się informacjami \\ - udział w procesie}

$$
\begin{aligned}
& \text { Techniki rozwiazywania konfliktów } \\
& \text { - wspólne rozwiązywanie problemów } \\
& \text { - perswazja } \\
& \text { - lagodzenie } \\
& \text { - dominacja } \\
& \text { - ostre słowa } \\
& \text { - arbitraż }
\end{aligned}
$$

Źródło: opracowanie na podstawie: J. Mohr, R. Spekman, Characteristics of Partnership Success: Partnership Attributes, Communication Behavior, and Conflict Resolution Techniques, ,Strategic Management Journal" 15/2 (1994), s. 137.

Według wyżej przywołanych autorów:

1. Miarą sukcesu partnerstwa jest satysfakcja uczestników relacji z przebiegu współpracy i poprawa ich konkurencyjności.

2. W literaturze wskazuje się na zaangażowanie, koordynację, współzależność i zaufanie, jako ważne atrybuty partnerstwa. Partnerzy uznają wzajemną zależność i podejmują działania na rzecz rozwoju relacji.

3. Proces komunikacji to krytyczny czynnik sukcesu relacji międzyorganizacyjnych. Efektywna komunikacja to warunek sine qua non, aby obie strony mogły uzyskiwać korzyści ze współpracy opartej na partnerskich relacjach. Kluczowymi aspektami transmisji informacji są: ich jakość, zakres dzielenia się informacjami i udział w planowaniu i wyznaczaniu celów.

\footnotetext{
${ }^{29}$ B. Maheshwari, V. Kumar, U. Kumar, Optimizing Success in Supply Chain Partnerships, „Journal of Enterprise Information Management” 19/3 (2006), s. 281, cyt. za: E. Małyszek, Czynniki wptywajace na sukces partnerstwa w tańcuchu dostaw - czy firmy rodzinne sa lepszymi partnerami?, „Logistyka” 2011/5, s. 1150.
} 
4. Nieodłącznym elementem partnerskich relacji międzyorganizacyjnych jest występowanie konfliktów, dlatego znajomość technik ich rozwiązywania jest ważnym czynnikiem sukcesu partnerstwa. Partnerstwo ma szansę odnieść sukces:

- im wyższy stopień wykorzystania konstruktywnych technik rozwiązywania konfliktów (wspólnego rozwiązywania i łagodzenia problemów, perswazji);

- $\quad$ im niższy stopień wykorzystania destruktywnych technik, w tym bazujących na dominującej pozycji jednego partnera;

- $\quad$ im niższy stopień wykorzystania zewnętrznego arbitrażu i technik unikania konfrontacji ${ }^{30}$.

Należy również wskazać na inny podział czynników wpływających na sukces partnerstwa, które przedstawiono w tabeli 3.

Tabela 3. Czynniki sukcesu partnerstwa przedsiębiorstw

\begin{tabular}{|l|l|}
\hline Kategoria & \multicolumn{1}{|c|}{ Czynnik sukcesu } \\
\hline \multirow{4}{*}{ Śodowisko } & Historia współpracy \\
\cline { 2 - 2 } & $\begin{array}{l}\text { Sprzyjające uwarunkowania ekonomiczne, polityczno-prawne, } \\
\text { sektorowe, geograficzne i socjokulturowe }\end{array}$ \\
\hline \multirow{4}{*}{$\begin{array}{l}\text { Proces budo- } \\
\text { wania i roz- } \\
\text { woju relacji }\end{array}$} & Dobór partnerów według kryteriów \\
\cline { 2 - 2 } & Udział obu partnerów w budowaniu i ciagłym doskonaleniu relacji \\
\cline { 2 - 2 } & Podział ryzyka i korzyści \\
\cline { 2 - 2 } & Zlastyczność \\
\cline { 2 - 2 } Zasadność do przystosowywania się (proces adaptacji) \\
\hline \multirow{4}{*}{ Komunikacja } & Właściwe tempo rozwoju relacji \\
\cline { 2 - 2 } & Kompreguły i wytyczne \\
\cline { 2 - 2 } & Wzajemny szacunek, zrozumienie i zaufanie \\
\cline { 2 - 2 } & Otwarte i częste komunikowanie się z partnerem \\
\hline \multirow{4}{*}{ Cele } & Wieformalne relacje i powiązania komunikacyjne \\
\cline { 2 - 2 } & Dostrzeganie we współpracy własnego i wspólnego interesu \\
\cline { 2 - 2 } & Konkretne i osiagalne cele i zadania \\
\cline { 2 - 2 } & Cele o charakterze strategicznym \\
\hline \multirow{3}{*}{ Zasoby } & Dażenie do uzupełnienia luk zasobowych \\
\cline { 2 - 2 } & Sprawne przywództwo \\
\cline { 2 - 2 } & Wykwalifikowani pracownicy odpowiedzialni za budowanie relacji \\
\hline
\end{tabular}

Źródło: opracowanie własne.

Ogół wyodrębnionych w tabeli 3 czynników sukcesu, które można określić jako stymulatory partnerstwa, podzielono na sześć kategorii: środowisko, proces budowania i rozwoju relacji, zasady, komunikacja, cele i zasoby. W obrębie wskazanych kategorii można wyróżnić kluczowe czynniki stymulujące rozwój relacji o charakterze partnerskim. Są to:

- przebieg dotychczasowej współpracy z danym partnerem oraz pozytywne doświadczenia wynikające ze współpracy z innymi podmiotami;

- sprzyjające uwarunkowania zewnętrzne: ekonomiczne, polityczno-prawne, sektorowe, geograficzne i socjokulturowe;

\footnotetext{
${ }^{30}$ J. Mohr, R. Spekman, op. cit., s. 137-138.
} 
- $\quad$ zaangażowanie partnerów w budowanie i ciągłe doskonalenie relacji, w tym tworzenie nieformalnych więzi;

- $\quad$ wspólnie uzgodniony podział ryzyka i korzyści;

- $\quad$ przestrzeganie wspólnie ustalonych zasad, na przykład wzajemnego szacunku i zaufania;

- $\quad$ otwarta i intensywna komunikacja;

- dążenie partnerów do realizacji określonych celów o charakterze strategicznym;

- $\quad$ dążenie partnerów do uzupełnienia pewnych niedoborów w sferze zasobów.

\section{PODSUMOWANIE}

Różnorodność ujęć definicyjnych czy płynność terminologiczna partnerstwa przedsiębiorstw wynika przede wszystkim z przesunięcia punktu ciężkości na jego różne atrybuty. Rzadko występującą w literaturze przyczynę wieloznaczności partnerstwa wskazuje Maria de Lurdes Veludo - według niej jest to „brak wspólnej wizji (strumienia) badań naukowych" ${ }^{\prime 31}$ dotyczącej jego istoty. Podejmując próby zdefiniowania partnerstwa, badacze wyznaczają jego granice nie tylko za pomocą specyficznych atrybutów, ale także wymiarów, krytycznych czynników i wskaźników sukcesu ${ }^{32}$.

W świetle przedstawionych rozważań przyjęto, że partnerstwo przedsiębiorstw to dobrowolne i dynamiczne relacje tworzone dla osiagnnięcia wspólnych celów, prowadzące do uzyskania dodatkowych efektów synergicznych i przewagi konkurencyjnej. Specyficznymi cechami tego typu relacji są przede wszystkim: wzajemne zaufanie partnerów, ich zaangażowanie we wspólne działania, podział ryzyka i korzyści oraz wzajemna wymiana informacji. Partnerstwo oddaje istotę ścisłej współpracy przedsiębiorstw i jest formą realizacji międzyorganizacyjnej strategii win-win, w której wygranymi są wszyscy uczestnicy układu partnerskiego. Ponadto partnerstwo kształtowane jest przez cztery zasadnicze elementy:

- $\quad$ zachowania i oczekiwania partnerów;

- $\quad$ zasoby posiadane przez partnerów przeznaczone na rozwój relacji partnerskich;

- $\quad$ proces budowania i doskonalenia partnerskich relacji;

- działania zmierzające do osiągnięcia celów współpracy.

W tym miejscu należy podkreślić, że kategoria partnerstwa nie określa, czego dotyczy działanie gospodarcze, w którego ramach jest realizowane (na przykład współpracy w procesie produkcji czy wymiany zasobów), i nie wskazuje konkretnych podmiotów, które mogą tworzyć i rozwijać partnerskie relacje, lecz wskazuje pewne cechy (wyznaczniki jakości) tej szczególnej formy relacji między przedsiębiorstwami. Inaczej rzecz ujmując, odpowiada na pytanie, jak partnerstwo powinno być realizowane. Powszechność występowania partnerskich relacji wpływa na warunki budowania przewagi konkurencyjnej i podwyższa bariery wejścia do sektora. W wypadku szerokiego zakresu i wysokiej efektywności partnerskich relacji $\mathrm{z}$ otoczeniem przedsiębiorstwa umacniają swoją przewagę

\footnotetext{
${ }^{31}$ M. de Lurdes Veludo, Business Relationships in the Automotive and Component Industries in Portugal, Ph.D. Thesis, School of Business and Management University of Glasgow, Glasgow 2005, s. 81, http://theses.gla.ac.uk/1544/1/2005veludophd.pdf (dostęp: 15.08.2014).

${ }^{32}$ Zob. P.W. Mattessich, M. Murray-Close, B.R. Monsey, Collaboration: What Makes It Work. A Review of Research Literature on Factors Influencing Successful Collaboration, Amherst H. Wilder Foundation, Saint Paul, Minnesota 2001, s. 7-29; M. de Lurdes Veludo, op. cit., s. 81-99.
} 
konkurencyjną, co potwierdzają wyniki badań empirycznych zaprezentowane w literaturze przedmiotu i wyniki obserwacji kształtowania relacji międzyorganizacyjnych.

\section{LITERATURA}

[1] Adamik A., A partnering approach to extending the business base through cooperation with competitors (coopetition) - is it an option for SMEs?, [w:] Recent Advances in Management, Marketing and Finances, red. A. Zaharim, R.G. Rodrigues, „Business and Economics Series” No. 4, WSEAS Press, Cambridge 2013.

[2] Adamik A., Rola kadry kierowniczej w budowie partnerstwa przedsiębiorstw, [w:] Organizacja i kierowanie, nr 3 (156), Komitet Nauk Organizacji i Zarządzania PAN i Kolegium Zarządzania i Finansów Szkoły Głównej Handlowej, Warszawa 2013.

[3] Brinkerhoff J.M., Government - Nonprofit Partnership: a Defining Framework, „Public Administration and Development" 22/1 (2002).

[4] Crowley L.G., Karim M.A., Conceptual Model of Partnering, ,Journal of Management in Engineering" 11/5 (1995).

[5] Czakon W., Fernandez A.S., Minà A., Editorial - From Paradox to Practice: the Rise of Coopetition Strategies, „International Journal of Business Environment” 6/1 (2014).

[6] Czakon W., Koordynacja sieci - wieloraka forma organizacji, „Przegląd Organizacji” 2008/9.

[7] Czakon W., Rogalski M., Coopetition Typology Revisited - a Behavioural Approach, „International Journal of Business Environment” 6/1 (2014).

[8] De Lurdes Veludo M., Business Relationships in the Automotive and Component Industries in Portugal, Ph.D. Thesis, School of Business and Management University of Glasgow, Glasgow 2005, http://theses.gla.ac.uk/1544/1/2005veludophd.pdf (dostęp: 15.08.2014).

[9] Foss N.J., Nielsen B.B., Researching Multilevel Phenomena: The Case of Collaborative Advantage in Strategic Management, ,Journal of Centrum Cathedra” 5/1 (2012).

[10] Hamel G., Doz Y.L., Prahalad C.K., Collaborate with Your Competitors and Win, „Harvard Business Review" 67/1 (1989).

[11] Hutt M.D., Speh T.W., Zarzq̨dzanie marketingiem. Strategia rynku dóbr i ustug przemystowych, PWN, Warszawa 1997.

[12] Jagoda H., Haus B., Holding - organizacja i funkcjonowanie, PWE, Warszawa 1995.

[13] Kempny D., Logistyczna obstuga klienta, PWE, Warszawa 2001.

[14] Kock S., Bengtsson M., Slotte-Kock S., To Compete or Cooperate - A Strategic Dilemma, „Journal of Business \& Industrial Marketing” 18/1 (2003).

[15] Latusek-Jurczak D., Formy wspótpracy międzyorganizacyjnej, [w:] Relacje międzyorganizacyjne $w$ naukach o zarzadzaniu, red. A.K. Koźmiński, D. Latusek-Jurczak, Wolters Kluwer business, Warszawa 2014.

[16] Maheshwari B., Kumar V., Kumar U., Optimizing Success in Supply Chain Partnerships, „Journal of Enterprise Information Management” 19/3 (2006), cyt. za: E. Małyszek, Czynniki wptywajace na sukces partnerstwa $w$ tańcuchu dostaw - czy firmy rodzinne sq lepszymi partnerami?, „Logistyka” 2011/5.

[17] Mattessich P.W., Murray-Close M., Monsey B.R., Collaboration: What Makes It Work. A Review of Research Literature on Factors Influencing Successful Collaboration, Amherst H. Wilder Foundation, Saint Paul, Minnesota 2001.

[18] Mezzadri A., Le partnership tra imprese e organizzazioni non profit, Universitŕ del Sacro Cuore, Milano 2008.

[19] Mohr J., Spekman R., Characteristics of Partnership Success: Partnership Attributes, Communication Behavior, and Conflict Resolution Techniques, „Strategic Management Journal” $15 / 2(1994)$.

[20] Moore J., Curry S.R., The Death of Competition, „Fortune” 133/7 (1996). 
[21] Niemczyk J., Jasiński B., Wstęp, [w:] Sieci międzyorganizacyjne. Wspótczesne wyzwanie dla teorii i praktyki zarzqdzania, red. J. Niemczyk, E. Stańczyk-Hugiet, B. Jasiński, C.H. Beck, Warszawa 2012.

[22] Nowak D., Stępień B., Powiazania kooperacyjne - wstępna charakterystyka relacji, [w:] Międzynarodowa kooperacja gospodarcza z polskiej perspektywy, red. B. Stępień, PWE, Warszawa 2011.

[23] Peace S., Partnerstwo w budownictwie, Poltext, Warszawa 2010.

[24] Rigsbee E., PartnerSHIFT. How to Profit from the Partnering Trend, John Wiley and Sons, New York 2000.

[25] Stańczyk-Hugiet E., Dynamika strategiczna w ujęciu ewolucyjnym, Wydawnictwo Uniwersytetu Ekonomicznego we Wrocławiu, Wrocław 2013.

[26] Stern L.W., El-Ansary A.I., Coughlan A.T., Kanaty marketingowe, PWN, Warszawa 2002.

[27] Sudolska A., Partnerstwo przedsiębiorstw jako czynnik rozwoju ich kompetencji strategicznych, „Prace Naukowe Uniwersytetu Ekonomicznego we Wrocławiu” 2010/116.

[28] Sudolska A., Uwarunkowania budowania relacji proinnowacyjnych przez przedsiębiorstwa $w$ Polsce, Wydawnictwo Naukowe Uniwersytetu Mikołaja Kopernika, Torun 2011.

[29] Sulejewicz A., Partnerstwo strategiczne: modelowanie wspótpracy przedsiębiorstw, Oficyna Wydawnicza Szkoły Głównej Handlowej, Warszawa 1997.

[30] Szydełko M., Szydełko Ł., Benchmarking w podejściu procesowym w przedsiębiorstwie wybrane zagadnienia, „Modern Management Review” XVIII/2 (2013).

[31] Witkowski J., Zarzadzanie tańcuchem dostaw. Koncepcje, procedury, doświadczenia, PWE, Warszawa 2003.

\section{ATTRIBUTES AND SUCCESS FACTORS OF INTERFIRM PARTNERSHIPS}

The formation of partnerships between firms is becoming an increasingly common way for firms to find and maintain competitive advantage. These relationships can be called partnering relations or partnerships, and currently they are widely applied in many industries. In theory and practice, the term partnering is used rather loosely and thus there is a need to define the elements that characterize partnering more exactly.

The aim of this article is to define the attributes of partnering relations and to identify the key factors that help a relationship to succeed. These attributes and success factors are analyzed from the theoretical point of view. Research issues determine the choice of research methods, such as: detailed analysis of the literature, both domestic and foreign and deductive reasoning. Interfirm partnerships are voluntary and dynamic relations are created to achieve common goals and synergy effects, and to find and maintain competitive advantage. Partnering relations are based on mutual trust, engagement, exchange of information (open and frequent communication), sharing of benefits and risks. The success of the partnerships, first of all, is based on history of collaboration, mutual respect and trust, strategic and attainable objectives, two-way information sharing, joint problem-solving, clearly defined and mutually-agreed goals, and mutual involvement in relationship development and planning.

Keywords: partnerships, relations, attributes, success factors

DOI: $10.7862 /$ rz.2014.mmr.59

Tekst złożono w redakcji: październik 2014

Przyjęto do druku: listopad 2014 